\title{
Parental worklessness and children's early school achievement and progress
}

Samantha Parsons, Institute of Education, University of London, UK

S.Parsons@ioe.ac.uk

Ingrid Schoon, Institute of Education, University of London, UK

Anna Vignoles, Faculty of Education, University of Cambridge, UK

(Received December 2012 Revised October 2013)

DOI: http://dx.doi.org/10.14301/llcs.v5i1.230

\section{Abstract}

In this paper we investigate the relationship between repeated parental worklessness and the academic progress made by children in England in their first full year of primary school. We draw on data from two recent longitudinal birth cohort studies with multiple rounds of data collection in the very early years up to age 5. We use the Avon Longitudinal Study of Parents and Children (ALSPAC) which started collecting data from more than 14,000 children and their families in a geographically defined catchment area in 1991/2, and the Millennium Cohort Study (MCS), which is a sample of 19,000 children and their families born across the UK around the turn of this century. We constructed measures of repeated (persistent) and temporary (intermittent) worklessness and found that both were associated with lower levels of early academic achievement and progress of children. This association cannot be fully explained by a number of other sociodemographic risks factors (including parental education, income, housing conditions and health), indicating independent risk effects. We furthermore could identify beneficial effects of a stimulating early home-learning environment, which were significant even after controlling for previous levels of children's cognitive and behavioural adjustment.

Keywords: parental worklessness, home-learning environment, longitudinal, early school performance

\section{Introduction}

Early cognitive development in childhood is a crucially important predictor of later developmental health (Hertzman et al., 2010; Marmot, 2010) and socio-economic outcomes (Hertzman et al., 2010; Marmot, 2010). Moreover, the early years have been identified as a crucial window of opportunity for interventions aiming to improve life chances (Heckman, 2006). However, it is also the case that a child's development and education attainment is strongly linked to their family's socio-economic status, broadly defined (e.g. Blanden, Gregg, \& Macmillan, 2007; Feinstein, 2003; Heckman \& Masterov, 2007; Gregg \& Macmillan, 2009; Jerrim \& Vignoles, in press; Schoon et al., 2002; Schoon, Hope, Ross, \& Duckworth, 2010). This strong relationship between family background, educational outcomes and subsequent adult outcomes has prompted much policy concern, particularly in the UK. For example, the recent Field Review on 'Poverty and Life Chances' (Field, 2010) has highlighted the important role of family background and parenting in determining a child's adult outcomes, particularly during the 'foundation years' before age 5 . Socio-economic status can be defined in a number of ways, and here we focus on the role of parental worklessness and its influence on early academic achievement and progress.

We add to the literature and policy debate in multiple ways. First, we assess the relative role of worklessness in shaping children's early development across different contexts. Second, we take into account the role of additional socio-economic 
risk factors that are associated with worklessness, to control for potential confounding factors. Third, we use longitudinal data to take into account the duration of worklessness. In particular we draw a distinction between repeated (persistent) and temporary (intermittent) parental worklessness during the child's early years. Fourth, we assess the role of a stimulating early home learning environment as a potential resource factor that might reduce the risk effect associated with the experience of repeated worklessness, over and above the other control factors included in the model.

Our study is guided by a developmentalcontextual approach, emphasizing multiple interacting influences on human development, the importance of formative years and the timing of events (Bronfenbrenner, 1986; Elder \& Caspi, 1988; Evans, 2006; Rutter, 1987; Sameroff, 2010; Schoon, 2006).

\section{Literature review}

\section{Worklessness and associated risks}

Worklessness is a particularly important aspect of socio-economic deprivation in the UK. Indeed the UK has a higher proportion of its children living in workless households than almost any other European Union country, second only to Ireland and almost twice that in France and Germany (Eurostat, 2010). $13 \%$ of households with dependent children were workless in the second quarter of 2011, which equates to just over one million workless households with dependent children (for reviews on household joblessness see also Office for National Statistics (ONS), 2011; De Graaf \& Ultee, 2000; Gregg \& Wadsworth, 2001). This situation is not likely to improve in the current economic situation with increasing pressures on families with dependent children (Brewer, Browne \& Joyce, 2011). Hence understanding the impact of worklessness on children's early cognitive development is of crucial importance.

The adverse long-term effects of growing up in a workless household have been shown in previous studies (Ermisch, Francesconi \& Pevalin, 2004; Macmillan, 2010, 2011). Living in a workless household has been found to be negatively associated with later educational and occupational attainment (McLanahan \& Sandefur, 1994; Haveman \& Wolfe, 1994; Cherlin, Kiernan \& ChaseLansdale, 1995; Kiernean, 1997; Schoon et al., 2012) and children growing up in poor or workless households are more likely to be workless or poor themselves as adults, as compared to children who grow up in households where someone is in work (Ekhaugan, 2009; Gottschalk, 1996; Gregg, Harkness \& Machin, 1999; Gregg \& Wadsworth, 2001; Such \& Walker, 2002; MacMillan, 2011; O'Neill \& Sweetman, 1998; Page, 2004). There is also some evidence that the risks for children's development from living in a workless household tend to be higher when they are younger (Duncan, BrooksGunn, Yeung, \& Smith, 1998; Ermisch et al., 2004) and that such experiences of socio-economic disadvantage in early childhood can set up a vicious cycle of cumulating disadvantage.

Existing research evidence also indicates that the relationship between any single risk factor, such as parental worklessness, and adult or child outcomes tends to be weak, and that usually many risks are involved in determining an outcome. Serious risk emanates from the accumulation of risk factors (Garmezy, 1991; Rutter, 1981, 2009). Since parental worklessness is associated with a number of other disadvantages faced by families (Evans, 2006; Ermisch et al., 2004), it is thus important that we understand the particular role parental worklessness plays in childhood development when taking into account such additional risk factors.

Parental worklessness is increasingly concentrated in certain subgroups of the population and in certain areas (Gregg \& Wadsworth, 2001). For instance around 2 in 5 lone parent households in the UK were workless in 2010, compared to 1 in 20 households with two parents ${ }^{i}$, and lone parents are more likely to experience poverty often as a result of being workless (Maplethorpe, Chanfreau, Philo \& Tait, 2010; Gingerbread, 2012). The least skilled are also more likely to be workless (Grinyer, 2006; Denny, Harman \& O'Sullivan, 2003; Dearden, McIntosh, Myck \& Vignoles, 2002; Mclntosh \& Vignoles, 2001; Machin, McIntosh, Vignoles. \& Viitanen, 2001; Vignoles, de Coulon, \& Marcenaro-Gutierrez, 2011; Groot \& Massed van der Brink, 2006), as are those experiencing family instability (Doiron \& Mendolia, 2011) and poor physical and mental health (McKeeRyan, Song, Wamberg \& Kinicki, 2005). An established body of literature has shown the association between poor mental health and wellbeing and unemployment, with the relationship being particularly strong for men (e.g. Clarke \& 
Oswald, 1994; Clarke, Georgellis \& Sanfey, 2001; Social Exclusion Unit Report, 2004). In our modelling we therefore take account of these other experiences and sources of deprivation to control for potential confounding factors, and to assess the independent effect of worklessness over and above these potential confounders.

We furthermore consider the duration of the risk effect. Most previous studies have conceptualised worklessness as a state, without taking into account that households may be moving in and out of worklessness over time. An earlier report for the Department for Education, Schoon et al (2012) considered the intergenerational transmission of repeated and temporary parental worklessness on a range of child and adolescent outcomes. We now add to this body of work by assessing the relationship between repeated versus temporary parental worklessness, and the academic progress of very young children in the UK context.

\section{The home-learning environment}

Previous studies have identified a number of potential resource factors that might counterbalance or neutralize the negative effects associated with exposure to early socio-economic adversity. Resource factors include, for example, positive parenting characteristics such as higher levels of education and the amount of time and energy parents invest in their children (Lerner \& Benson, 2003; Rutter, 1987, 2006; Masten, 2009; Schoon, 2006). For example, more involved parenting has been associated with better adjustment than expected among children exposed to socio-economic adversity (Bradley, Corwyn, McAdoo \& Coll, 2001; Melhuish et al., 2008). In this paper we focus on the role of the early homelearning environment during the first three years of life on later academic performance, to assess its long-term benefit over and above a number of other control factors, such as variations in earlier cognitive performance and child behaviour adjustment. Previous research has mostly focused on the long-term benefits of early pre-school education provision (George, Stokes, \& Wilkinson, 2012; Sylva, Melhuish, Sammons, Siraj-Blatchford, \& I. Taggart, 2010), although not all children, especially the most disadvantaged, are making use of this provision. A growing body of evidence suggests that the early home learning environment is one of the most important factors in explaining income-related gaps in cognitive development, especially during the early years (Dearden, Sibieta, \& Sylva, 2011; Melhuish et al., 2008; Washbrook, 2010). Key indicators of early home-learning include parent's reading to the child, teaching behaviour and early skills, encouraging literacy activities, library visits, as well as establishing rules and regularity of routines, which form the basis of the home learning measures included in this paper (see also Bradley, Corwyn, McAdoo, \& Coll, 2001; Kelly, Kelly, \& Sacker, 2013).

Regarding the longer-term benefits of the early home-learning environment, previous research suggests that its influence on later levels of cognitive attainment is largely mediated through earlier levels of attainment, i.e. school readiness (Dearden et al., 2011). This study however focused especially on income inequalities. Here we want to assess the role home-learning has in reducing the effect of repeated parental worklessness on children's cognitive development. It might be that a positive home-learning environment can offset any negative impact from worklessness, or even that workless parents can spend more time with their children to teach them and interact with them than parents who are employed (especially the working poor who often have more than one job).

In considering the role of the home-learning environment in reducing the negative impact of parental worklessness, we control for a number of other socio-economic confounders identified above, as well as child characteristics, such as early birth weight, age at time of assessment, health status and previous levels of cognitive and behavioural adjustment. This is done in order to take into account, that parental investments and interactions with their children might vary depending on the child's characteristics, e.g. the child's age, health, and adjustment across domains (Belsky, 1984). It is assumed that the early homelearning environment will have a beneficial effect on the child's cognitive development, reducing at least some of the negative effect of parental worklessness. Given the problems in establishing interactive effects (Rutter, 1987), we focus on main effects of the early home-learning environment.

Drawing attention to differences between families experiencing repeated or temporary worklessness, the specific research questions that we address are:

1. To what extent are workless families exposed to a number of additional risk factors, such as 
poverty, low levels of education, family breakup, lone parenthood, long-term illness, overcrowded housing conditions, and area deprivation?

2. Does parental worklessness have an independent association with children's early academic attainment after controlling for other associated risk factors?

3. Do characteristics of the early home-learning environment reduce the negative association between parental worklessness and child academic outcomes at age 5 ?

4. Is the influence of the early home-learning environment on later levels of cognitive attainment largely mediated through earlier levels of cognitive attainment and behaviour adjustment?

\section{Data and Methods \\ Data}

In this paper we use two rich longitudinal data sets, namely the Avon Longitudinal Study of Parents and Children (ALSPAC) and the Millennium Cohort Study (MCS), to investigate the relationship between parental worklessness and children's cognitive achievement in early childhood. The ALSPAC cohort were born in the early 1990s and the outcomes we consider date from the mid-1990s, a period of weak economic growth. The MCS data relate to children born in 2000, and the outcomes were observed during the period of more rapid economic growth in the early 2000s. Comparisons across the two data sets are difficult, since, unlike the nationally representative MCS, the ALSPAC data set only relates to one particular (relatively affluent) region of the UK. Nonetheless, comparing the experiences of children and their parents in the two data sets gives us an opportunity to test the robustness of any findings across differing sociohistorical contexts and economic conditions.

ALSPAC is an ongoing population-based cohort study (Golding, Pembrey, Jones \& the ALSPAC study team, 2001). To be eligible to participate in the study, mothers had to be resident in the former Avon Health Authority while pregnant, with an expected date of delivery between 1st April 1991 and 31st December 1992. More than $80 \%$ of the known births from the geographically defined catchment area were included, resulting in a total cohort of 14,062 live births. The study contains a wealth of data on family background, family process, the cognitive, social and behavioural development of children, and key features of the school environment. In addition, school-level data including Local Education Authority (LEA) entry assessment scores (age 5) were obtained, and administrative data from the National Pupil Database (NPD) have been merged with the ALSPAC data. These data cover all relevant state schools in four LEAs; Bristol, South Gloucestershire, North Somerset, and Bath and North East Somerset.

MCS is an ongoing survey of 18,818 babies born between September 2000 and January 2002 into 18,552 families living in the UK (Hansen, 2010). Data collections took place at ages 9 months, 3, 5, and 7 years. In this research we use data from the first three waves of data collection, from age 9 months in 2001/2 to age 5 in 2004/5. Data have been collected from parents, children, teachers and health visitors, comprising personal interviews and self-completion questionnaires. The data include information on socio-demographic family characteristics, children's cognitive, social, emotional and behavioural development, gender roles, health and well-being. Foundation Stage Profile scores (FSP), completed by all teachers for children in England in the first year of primary school (age 5) together with administrative data from the National Pupil Database (NPD) that have also been merged with the MCS data. As the outcome measures are only available for children in England, analysis is restricted to families living in England. At sweep 1, 11,533 families lived in England.

\section{Analytic sample}

The longitudinal sample of families who participated in each of the three or four waves of data collection formed the analytic sample for this paper. This consisted of 6,942 ALSPAC families (approximately $65 \%$ of all families who completed a questionnaire when the child was 8 months of age) ${ }^{\mathrm{ii}}$ and 8,252 MCS families living in England (72\% of sweep 1 families living in England). Despite disadvantaged families being more likely to have dropped out of both studies over time, as in all longitudinal studies (e.g. Plewis, 2007; Elliott \& Shepherd, 2006), the longitudinal sample of MCS families have a similar distribution to the original sample of families along key dimensions such as parental education, family status, ethnicity and housing tenure. However, in ALSPAC, differences between the longitudinal sample and all families 
participating at sweep 1 were statistically significant at the $p<.05$ level in all bar one of the measures included. Children and their parents in the longitudinal sample are, as expected, more advantaged. For example, parents in the longitudinal sample are marginally more educated. Thus our analysis probably underestimates the extent of worklessness in the population being considered. If those experiencing the most negative outcomes from worklessness in childhood are more likely to leave the study, we may be underestimating the negative impact from worklessness. That said, the differences between the longitudinal and the eight month questionnaire sample, defined in this study as the first sweep, are not large. See table A3 in the appendix for details of the representativeness of the longitudinal sample of families in both studies.

\section{Measurement \\ Measuring repeated versus temporary worklessness}

A workless family was defined as a family where no parent living in the household was in work at the time the family was interviewed. We look at worklessness in 2-parent families (both parents are not in work) and single parent families (parent not in work). As the data sets are longitudinal, we were able to identify families who were:

- never workless at any of the assessment points (continuously working)

- moving in and out of worklessness (temporary worklessness)

- workless at all assessment points (repeated worklessness).

It is important to note that, it cannot be assumed that families who were identified as repeatedly workless, were workless throughout the whole period, as we lack continuous data on the work status of each household and there might have been some fluctuation in household circumstances between observation points. The discussion of repeated worklessness is therefore subject to this caveat.

There were more potential counts of parental worklessness between birth and age five for the ALSPAC cohort, as data were collected more regularly than for MCS. To aid consistency, we measure parental worklessness in ALSPAC when the cohort child was closest to the age when parental worklessness was first observed for MCS children. As such, information on parental worklessness was collected from four waves of data collection in ALSPAC (postal self-completion questionnaires) and three waves in MCS (interviews). ALSPAC children were 8 months, 1 year 9 months, 2 years 9 months and 3 years 11 months of age. MCS children were 9 months, 3 years and 5 years of age.

\section{Measures of early academic progress}

We focused on mathematics and reading outcomes for children during their first year of primary school, around age 5. For ALSPAC children we used Entry Assessment (EA) scores and for MCS children, Foundation Stage Profile (FSP) scores ${ }^{\text {iii. }}$.

\section{Entry Assessments (ALSPAC)}

The primary purpose of the Entry Assessment (South Gloucestershire Professional and Curriculum Support Service, 1996) was to measure the strengths and needs of pupils on entry to school, and to provide a baseline against which progress could be measured at the end of Key Stage 1, the end of Year 2 in primary school when children are age 7. The Entry Assessment (EA) was teacher-administered and made up of four required areas, language, reading, writing and mathematics, each marked on a scale of $2-7$. Here we concentrate on the reading and mathematics scales, which are crucial for later school success:

- Entry reading: covers a range of reading skills, such as whether the child can talk about the pictures in a book.

- Entry mathematics: covers a wide range of skills which include understanding pairs, matching colours and counting.

\section{Foundation Stage Profile (MCS)}

Assessments are made on the basis of the teacher's accumulating observations and knowledge of the whole child. By the end of the final year of the foundation stage, the Foundation Stage Profile (FSP) provides a way of summing up that knowledge. It captures the early learning goals as a set of 13 assessment sub-scales, each of which has a scale of 0 to 9 points (for further details see Foundation Stage Handbook, QCA, 2003). To be able to compare the FSP mathematics and reading scores with the EA scores for ALSPAC children we use four of the 13 scales:

- Reading: whether the child has developed an interest in books for example or can recognise a few familiar words.

- Mathematics: this scale combines three subscales with a scale of 0 to 27 . It gives a profile score for mathematics including number and counting, calculating and shape, space and measures. 
All EA and FSP scores are standardised to have a mean of zero and a standard deviation of one.

\section{Associated risks}

We are able to allow for a range of additional risk factors that have been shown to be associated with parental worklessness and child academic attainment, as discussed in the literature section above. We include family characteristics such as highest held qualification and marital status, parental health and living conditions, experience of poverty and family size. These risks are quite similarly measured across the two studies with 'status' taken at the first sweep of data collection used in this paper for ALSPAC families and at sweep 1 for MCS families, when children were 8 months and 9 months respectively, which further enhanced comparability. We also control for income, however this variable is not measured in a similar way in the two data sets. We therefore use family income in ALSPAC, which was first measured when the child was 2 years and 9 months of age and a measure of income poverty at sweep 1 for MCS. The variable measuring overcrowded living conditions is not available in the first sweep of data and is measured at the last sweep of data collection in both studies. Some variables are time-varying, specifically, change in marital status, gaining qualifications or studying for an exam. An additional area-based measure was also included in the MCS analysis, namely the index of multiple deprivation (IMD). This was to take account of the different economic conditions prevailing across England. Further details of the measures specific to each study are included in Appendix Tables 3 and 4.

\section{Child characteristics}

We control for a number of child characteristics, including age, gender, earlier cognitive performance ${ }^{\text {iv }}$, behaviour difficulties, and physical health. Regarding prior cognitive performance we have information about a child's vocabulary measured directly at age 3 in both studies. In ALSPAC, vocabulary was captured by the MacArthur Communicative Development Inventories (Fenson et al., 1993) and in MCS by the British Ability Scales Naming Vocabulary assessment (Elliott, 1983, 1996; Elliot, Smith \& McCulloch, 1996). Behaviour was assessed via maternal report: in ALSPAC by the Rutter Parent Scale for Preschool Children (Elander \& Rutter, 1996), in MCS by the Strengths and Difficulties questionnaire (Goodman, 1997). ALSPAC children were age 3.5 years, MCS children were age 3 at the time of assessment.
Physical health included birthweight, general health and long-standing illness. These measures were reported by the parent-figure at interview in MCS and in a self-completion questionnaire in ALSPAC.

\section{Early home-learning environment}

Indicators of the home-learning environment were assessed at age 3 in MCS and between 2 years and 3 years 6 months in ALSPAC. Measures included reading to the child, taking child to the library, parents teaching their child the alphabet, numbers/counting and songs (summarized as a teaching score) and having a regular bedtime.

As with the associated risks, there was much similarity in the measures available in both studies. Further details of all child characteristics and homelearning factors and their association with parental worklessness, can be found in Tables 3 and 4 .

\section{Analytic strategy}

Data analysis was carried out in Stata 12. Our strategy for addressing the research questions (RQ) is as follows. After first establishing the prevalence of worklessness in the two studies, we use linear regression to predict the number of times a family was workless (RQ1). We present two models. The first is estimated using OLS and uses the workless variable as a continuous measure with a range 0 to $3+^{v}$. An alternative specification is also presented to explore the distinctions between the different types of worklessness, namely a logistic regression model which predicts never being workless versus temporary worklessness ( $0 \vee 1-2$ periods of worklessness), and temporary worklessness versus repeated worklessness (1-2 periods of worklessness $v 3+$ periods of worklessness). We then used linear regression to assess the relationship between parental worklessness and the child's reading and mathematics achievement during the first year of schooling (RQ2RQ4). For each child outcome (i.e. standardised EA scores for ALSPAC children and FSP scores for MCS), five separate regression models were estimated. Firstly we describe the initial direct relationship between family worklessness and the outcome measure (Model 1), i.e. not allowing for other factors that may influence both worklessness and child test scores. We then add the associated risks factors (Model 2), identified from the earlier analysis to predict worklessness (addressing RQ2). In Model 3 we add child characteristics and in Model 4 we added indicators of the early home environment (RQ3). Model 5 included all measures (RQ4). 


\section{Results}

\section{Prevalence of parental worklessness}

We found that about 1 in 10 of ALSPAC families and 1 in 6 of MCS families were workless at each of the three or four time points captured by this study. Looking at the experience of worklessness longitudinally, $17.8 \%$ of ALSPAC families and $23.1 \%$ of MCS families had experienced a period of worklessness. More families in MCS had experienced long-term repeated worklessness: $8.1 \%$ had been workless at all three interviews compared with the $6.1 \%$ of ALSPAC families who had been workless at three or four observation points. As established in the literature, lone-parent families are heavily overrepresented among the workless. In the longitudinal samples, $49 \%$ of lone parents, when the child was eight months old, had experienced long-term repeated worklessness in ALSPAC, as had 39\% of lone parents when the child was nine months old in MCS. Comparable figures for married couples were 3\% and $2 \%$ respectively. Small numbers, particularly in ALSPAC, restricted running separate additional analyses on lone parents, but this will be reported in a forthcoming paper concentrating on MCS families. Family status and changes over time are controlled for in the regression models.

MCS is representative of all the UK, whereas ALSPAC data were collected in the South West region. The incidence of workless families in the South West is similar to that observed in the ALSPAC data roughly 10 years earlier $23.1 \%$ of all MCS families had experienced at least one episode of worklessness, $16.4 \%$ of MCS families in the South West had experienced worklessness, as had $17.8 \%$ of ALSPAC families). As noted earlier, the 1990s were less economically prosperous than the beginning of the millennium.

\section{Parental worklessness and associated risk factors (RQ1)}

Bivariate correlations, between our measure of worklessness and all the variables included in the regression models, varied between -.00 and .60 . The highest correlations were found between parental worklessness and income poverty (.60) in MCS and weekly income in ALSPAC (.51). These measures of income were included in the analyses, given the evidence regarding the importance of both income and working status on outcomes for young children outlined in the introduction. Other strong correlations were between qualifications and income (.49 MCS, .46 ALSPAC) and parental worklessness and qualifications in MCS (.48), but this relationship was weaker in $\operatorname{ALSPAC}(.28)$.

Table 1 (ALSPAC) and Table 2 (MCS) show the results from the different multiple regression models. There was considerable consistency across both data sets and the different models, suggesting similar patterns regarding the association between parental worklessness and other socio-demographic risk factors. In both cohorts the experience of temporary or repeated worklessness was significantly associated with cohabitation and single parenthood, with one or more family transitions (separating from a partner or forming a union), low income, living in social housing or private rented and overcrowded accommodation, having poor general health or a long term limiting illness. It was also significantly associated with low parental education in both cohorts, although in ALSPAC parents with level 2 or 3 qualifications ('O'Levels or 'A'Levels) were significantly less likely than parents with a degree to experience worklessness. Additional significant associations with worklessness found for MCS families only, were being a younger mother, not gaining further qualifications between wave 1 and 3, maternal depression and the family living in an area with higher deprivation (as measured by an Index of Multiple Deprivation).

The findings suggest some differences between the workless groups. For example, the experience of repeated rather than temporary worklessness appeared to be more likely for those families with lower qualifications and poorer health (MCS). Temporary worklessness was more strongly associated with family instability, overcrowded living conditions and low income - particularly in MCS. Most of the different risk factors showed an independent risk effect, i.e. they were associated with worklessness over and above the other factors included in the model, suggesting that to understand the experience of worklessness and its impact on child outcomes, it is necessary to take into account these multiple interlinked risk factors. 
Table 1. Predicting worklessness in ALSPAC area in early-mid 1990s

\begin{tabular}{|c|c|c|c|c|}
\hline & \multirow{2}{*}{\multicolumn{2}{|c|}{$\begin{array}{l}\text { Linear Regression } \\
\text { No. of times } \\
\text { workless ( } 0 \text { to } 3 \text { ) }\end{array}$}} & \multicolumn{2}{|c|}{ Logistic Regression } \\
\hline & & & \multirow{2}{*}{$\begin{array}{c}0 \text { workless v } \\
1-2 \text { workless } \\
\text { Odds Ratio } \\
(95 \% \mathrm{Cls})\end{array}$} & \multirow{2}{*}{$\begin{array}{c}\text { 1-2 workless v } \\
\text { 3-4 workless } \\
\text { Odds Ratio } \\
\text { (95\% Cls) }\end{array}$} \\
\hline & $\boldsymbol{\beta}$ & SE & & \\
\hline Age of mother at birth & -.02 & .002 & 0.99 & 1.03 \\
\hline (years) (S1) & & & $(0.97-1.01)$ & $(1.00-1.06)$ \\
\hline Ethnicity (S1) & & & 1.17 & 0.62 \\
\hline $0=$ White, $1=$ other & -.01 & .049 & $(0.70-1.93)$ & $(0.32-1.23)$ \\
\hline Housing tenure (S1) & $.25^{* * *}$ & .031 & $1.89 * * *$ & $3.14^{* * *}$ \\
\hline $0=$ own, $1=$ rent (social) & & & $(1.42-2.50)$ & $(2.19-4.51)$ \\
\hline \multirow[t]{2}{*}{$0=o w n, 2=$ rent (private) } & $.07 * * *$ & .042 & $1.69 * *$ & $1.97 * *$ \\
\hline & & & $(1.15-2.49)$ & $(1.18-3.28)$ \\
\hline \multirow[t]{2}{*}{$0=$ own, $3=$ other } & .01 & .054 & 1.24 & 0.95 \\
\hline & & & $(0.72-2.14)$ & $(0.40-2.27)$ \\
\hline Overcrowded home: $1+$ per & $.03^{* *}$ & .021 & $1.45^{* * *}$ & 1.19 \\
\hline room (S3) & & & $(1.18-1.80)$ & $(0.86-1.64)$ \\
\hline \multicolumn{5}{|l|}{ Highest qualification } \\
\hline (household) (S1) & & & 1.03 & 1.60 \\
\hline $0=$ degree, $1=A^{\prime}$ Level & $-.04 * *$ & .023 & $(0.75-1.41)$ & (0.81-3.19) \\
\hline \multirow[t]{2}{*}{$0=$ degree, $2=\mathrm{O}^{\prime}$ Level } & $-.06 * * *$ & .025 & 1.02 & 1.41 \\
\hline & & & $(0.74-1.43)$ & $(0.71-2.81)$ \\
\hline \multirow[t]{2}{*}{$0=$ degree, $3=$ vocational } & .00 & .041 & 1.04 & $2.13^{*}$ \\
\hline & & & $(0.66-1.64)$ & $(1.00-4.58)$ \\
\hline \multirow[t]{2}{*}{$0=$ degree, $4=C S E$} & $.03 *$ & .037 & 1.27 & $2.28^{*}$ \\
\hline & & & $(0.85-1.90)$ & (1.11-4.68) \\
\hline \multirow[t]{2}{*}{ Mother took exam (S4) } & -.00 & .030 & 1.19 & 0.81 \\
\hline & & & $(0.86-1.65)$ & $(0.48-1.36)$ \\
\hline Weekly family income (S3)1= & & & $0.41 * * *$ & $0.43^{* * *}$ \\
\hline$f 400+\ldots .5=<£ 100$ & $.32 * * *$ & .009 & $(0.37-0.46)$ & $(0.35-0.53)$ \\
\hline \multicolumn{5}{|l|}{ Marital status (S1) } \\
\hline \multirow[t]{2}{*}{$0=$ married, $1=$ cohabiting } & $.05 * * *$ & .023 & $1.53^{* * *}$ & 1.09 \\
\hline & & & (1.21-1.94) & $(0.77-1.56)$ \\
\hline \multirow[t]{2}{*}{$0=$ married, $2=$ single parent } & $.20 * * *$ & .051 & $2.14^{* *}$ & $3.22^{* * *}$ \\
\hline & & & $(1.27-3.58)$ & $(2.02-5.14)$ \\
\hline \multicolumn{5}{|l|}{ No of marital transitions } \\
\hline \multirow[t]{2}{*}{ (S1-S4) range: $0=$ none, $1=1+$} & $.13^{* * *}$ & .024 & $3.30 * * *$ & $0.63 * * *$ \\
\hline & & & (2.63-4.14) & $(0.50-0.80)$ \\
\hline \multicolumn{5}{|l|}{ Physical health (S1 - S4) } \\
\hline $0=$ always well, $1=$ sometimes & $.02 *$ & .030 & 1.11 & 1.47 \\
\hline unwell & & & $(0.79-1.55)$ & $(0.92-2.34)$ \\
\hline \multicolumn{3}{|l|}{ Mother depression score (S1) } & 1.03 & 0.99 \\
\hline \multirow[t]{2}{*}{ (range: 0-16) } & .01 & .003 & $(1.00-1.06)$ & $(0.95-1.04)$ \\
\hline & 0.42 & & & \\
\hline \multicolumn{2}{|l|}{ Nagelkerke $\mathrm{R}^{2}$} & & 0.28 & 0.21 \\
\hline $\mathrm{N}$ & 5,855 & & 5,506 & 1,012 \\
\hline
\end{tabular}

Note. $S 1=8$ months; S1=1 year 9 months; 2 = 2 years 11 months; S4 = 3 years 11 months 
Table 2: Predicting worklessness in MCS in early-mid 2000s

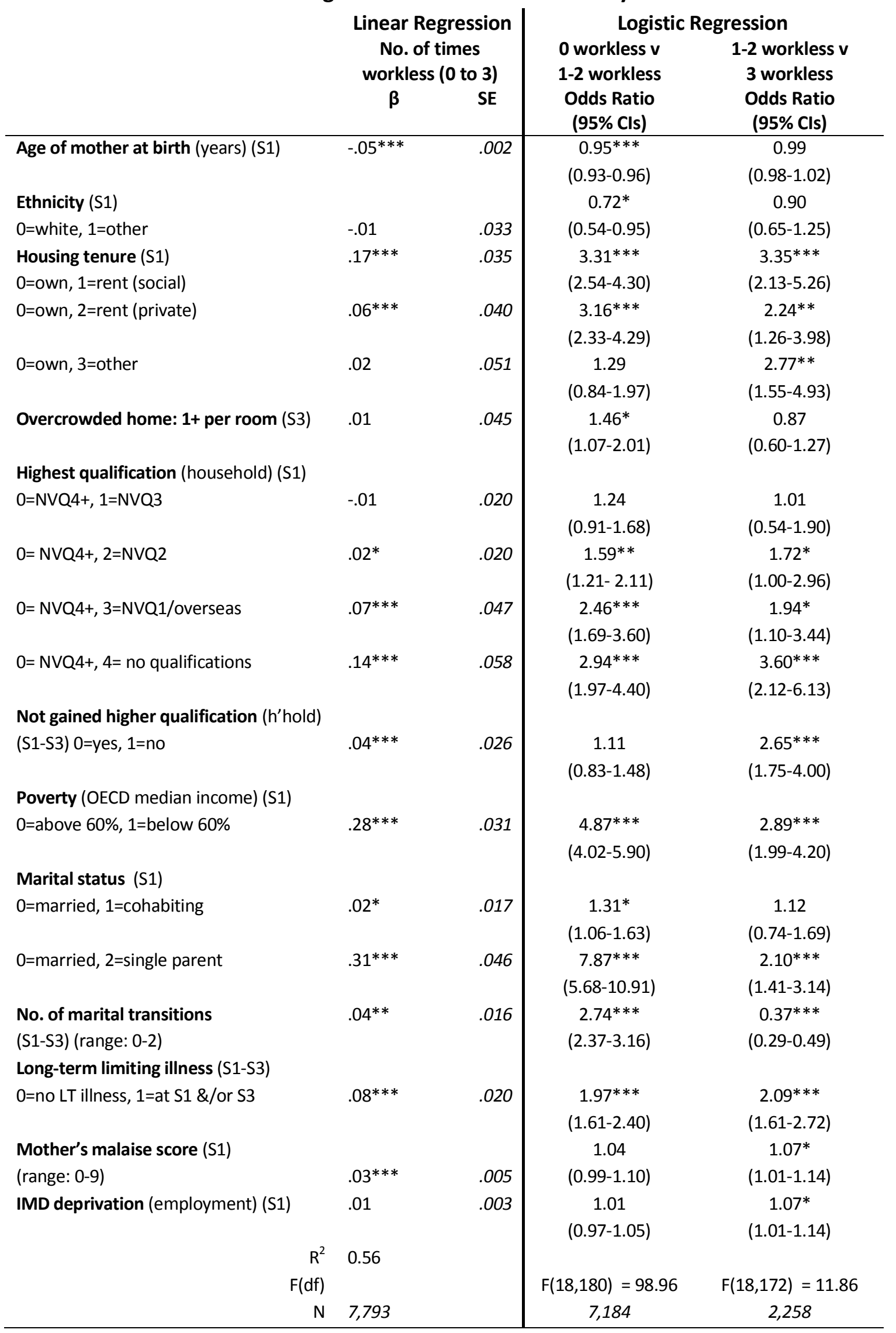

Note. $S 1=9$ months; $S 2=3$ years; S3 = 5 years 


\section{Parental worklessness, child characteristics and home-learning}

Descriptive analysis showed children growing up in workless families were more likely to have poorer health and behaviour difficulties, especially in MCS (see Table A1 [ALSPAC] and Table A2 [MCS] in the appendix). Although parental worklessness was not strongly associated with our measures of parent teaching their child at an early age, workless parents were less likely to read to their child on a daily basis, to take their child to the library, and less likely to observe regular bedtimes for their child especially repeatedly workless parents.

\section{Parental worklessness and children's early school achievement}

Exposure to temporary and repeated parental worklessness was associated with lower reading and mathematics attainment scores for children in both cohorts. Figure 1 shows that the strongest associations were found for repeated parent worklessness in both cohorts, although the experience of worklessness, even at only one of the time-points, was already significantly associated with lower attainment scores in comparison to the scores of those children with persistently working parents.

\section{Figure 1: Standardised mean reading and mathematics attainment scores}

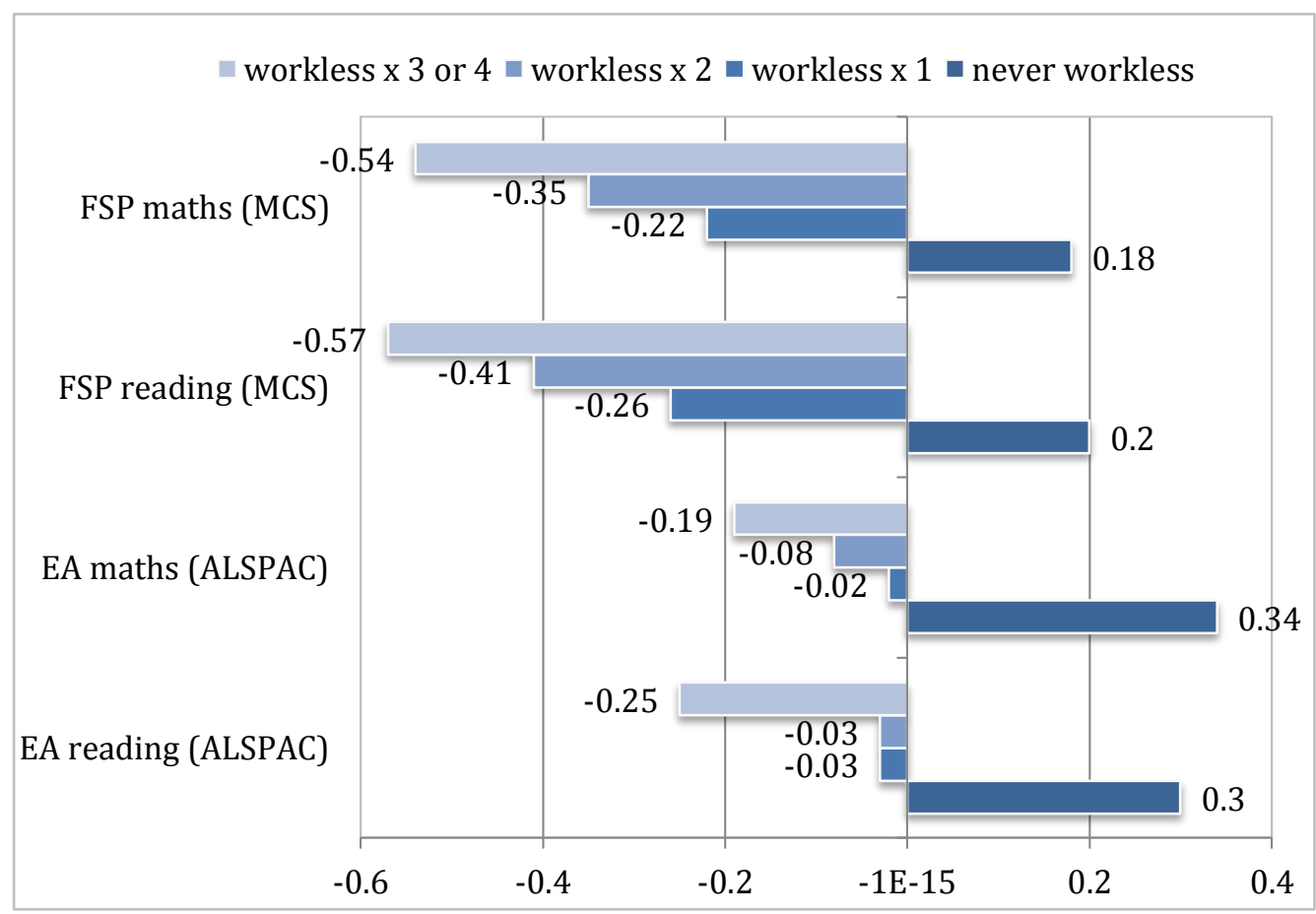

From the raw standardised mean scores shown in figure 1, it appears that there is a stronger association between parental worklessness and poor attainment in the MCS data than in the ALSPAC data, but this result has to be interpreted carefully. It may well be that for the MCS cohort, growing up during a more prosperous period, those who were workless were relatively more disadvantaged than those who were workless in the ALSPAC cohort (growing up during difficult economic conditions). Without controlling for the range of other risk factors that are correlated with worklessness and also likely to negatively impact on child attainment, we may thus wrongly ascribe the poor outcomes of the children to the worklessness these families experience. This problem essentially arises due to selection into worklessness on the basis of factors we do not observe in our data.

Concentrating now on the results from the multiple regression analyses to answer RQ2 to RQ4, figure 2 (mathematics) and figure 3 (reading) give the standardised beta coefficients measuring the relationship between repeated worklessness and the particular assessment score for each of the five separate models. A bar with a value greater than 0 indicates that children with repeatedly workless parents had higher scores than children living with 
persistently working parents; a bar with a value less than 0 indicates that children with repeatedly workless parents had lower scores than children living with persistently working parents. The greater the value of a bar, in either direction, the stronger the association between parental worklessness and the child's assessment score.The results show that the original association between parental worklessness and early school performance was much stronger for MCS children than for ALSPAC children. Once the associated risk factors were taken into account (RQ2), a much weaker, though statistically significant relationship between repeated parental worklessness and early school attainment outcomes remained in both studies. This indicates that in both studies the relationship between parental worklessness and early school academic progress is largely, but not fully, explained by other risk factors.

By adding child characteristics and indicators of the early home-learning environment separately to the regression model, we can see that the relationship between parental worklessness and reading and mathematics scores remained statistically significant in the models for children in both cohorts. For ALSPAC children, the additional reduction in the association between parental worklessness and the outcome scores was negligible when child characteristics or homelearning environment measures (RQ3) were included, although in the MCS, child characteristics appear to play a more significant role.

However, once both child characteristics and indicators of the early home learning environment were included in the model (RQ4), repeated parental worklessness remained significantly associated with reading and mathematics scores for ALSPAC and MCS children. Temporary worklessness also remained significantly associated with mathematics scores for both MCS and ALSPAC children.

The results suggest that parental worklessness, and in particular repeated worklessness, was a risk factor associated with poor early school achievement for ALSPAC and MCS children. Much (but not all) of this association was attributable to other family socio-demographic characteristics. Despite the differences between the two data sets that we are analyzing, particularly the different time periods and the different geographies, we find that the negative association between parental worklessness and early child achievement holds in both data sets. This association remains even when we control for a full range of other socio-economic risks, child characteristics and measures of the home learning environment including the child's ability as captured by performance in earlier assessments. Hence this negative relationship appears to apply in different historical, social and economic contexts.

Figure 2. Regression coefficients for repeated worklessness and standardised early school achievement mathematics scores in ALSPAC and MCS

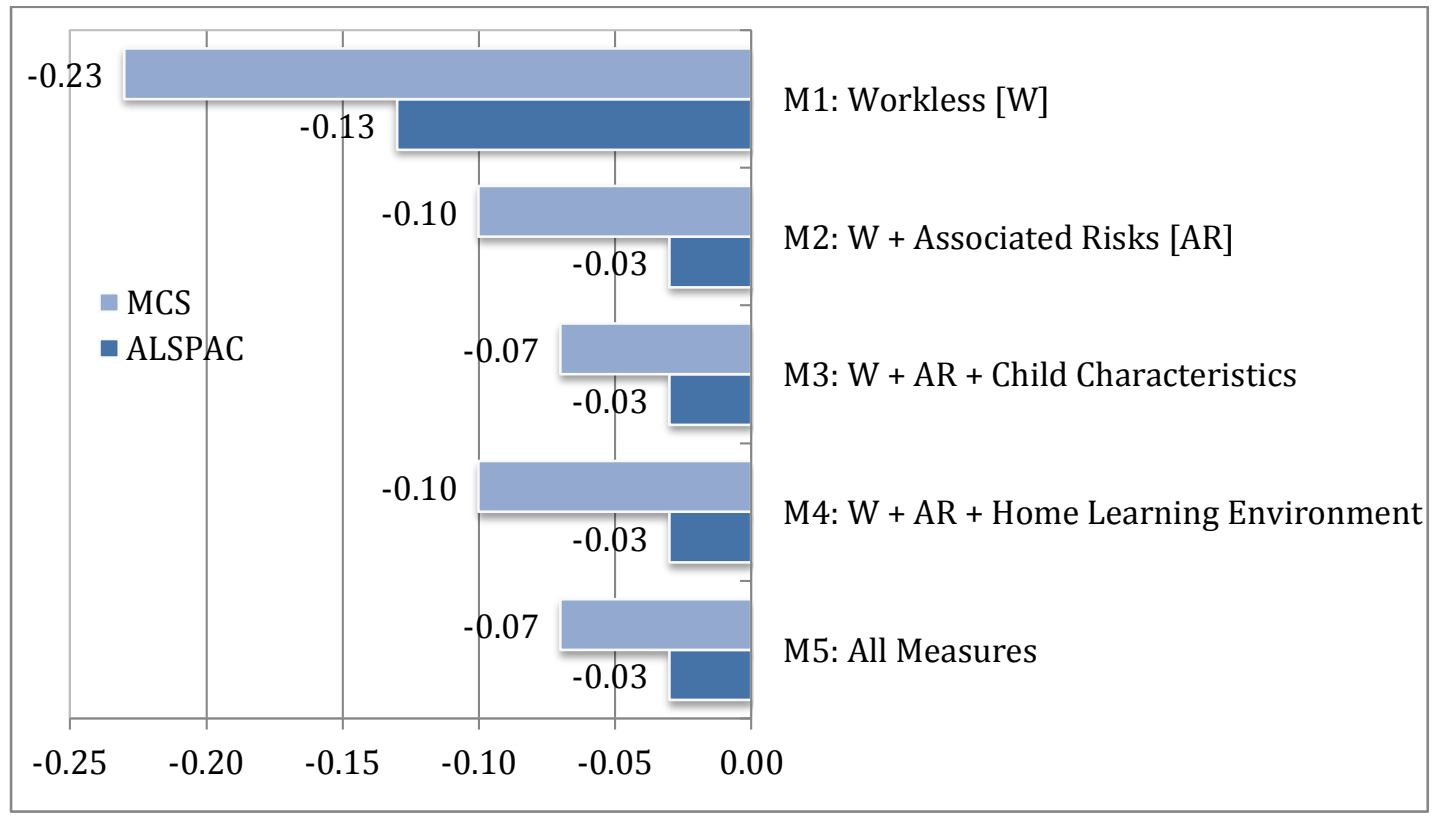




\section{Figure 3. Regression coefficients for repeated worklessness and standardised early school achievement reading scores in ALSPAC and MCS}

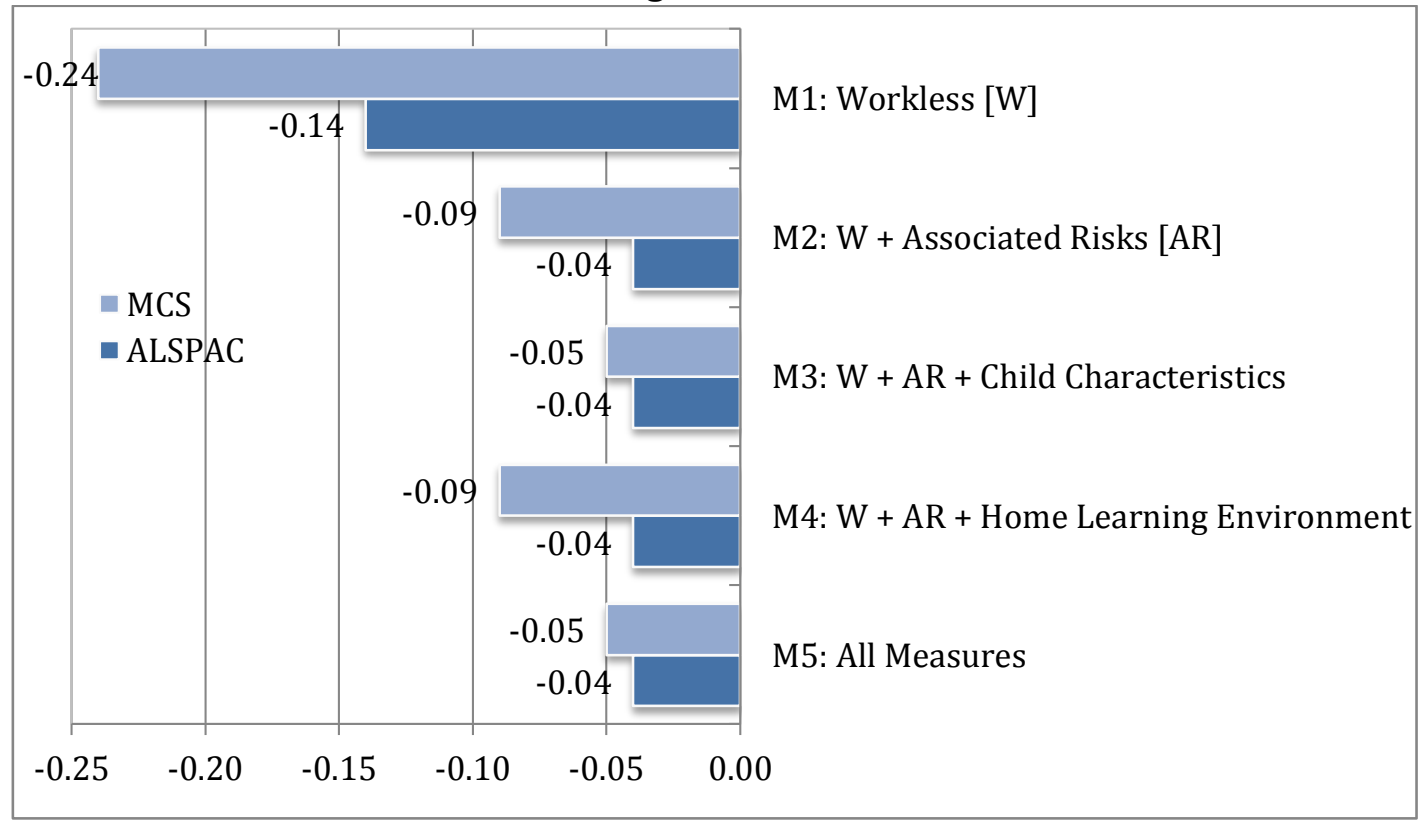

\section{Which factors had an independent association with early school achievement?}

Table 3 (ALSPAC) and table 4 (MCS) detail the results for the final model which includes all associated risks, child characteristics and the homelearning environment (Model 5).

\section{Associated risks}

After controlling for all other variables in the model, some of the family socio-economic risk factors remained negatively and significantly associated with early school performance of children. In both cohorts these risks were lower parental education levels, social or private rented, and overcrowded living conditions (especially regarding mathematics scores). Being part of a minority ethnic family was also significantly negatively associated with reading performance among MCS families, as was having a low weekly income and being a younger mother for the reading and mathematics scores of children in ALSPAC families.

\section{Child characteristics}

The child's earlier level of language ability, as measured by (different) assessments of their vocabulary score, was identified as the most significant potential resource factor. However, being an older child was also significantly associated with early school achievement in both studies, after controlling for all the other variables in the model. Being female was associated with higher mathematics and reading scores in ALSPAC, and higher reading scores in MCS. Higher birth weight was also significantly associated with higher mathematics scores in ALSPAC, and not having behaviour problems in early childhood was associated with higher mathematics and reading performance in MCS.

\section{Home Learning Environment}

Reading to the child and teaching them the alphabet, numbers and songs at an early age were both significantly associated with the child's school achievement in reading and mathematics in both studies. Having regular bedtimes was also significantly associated with good performance scores in reading and mathematics in MCS, but only with mathematics performance in ALSPAC. Being regularly taken to a library was also significantly associated with school achievement in ALSPAC, as well as with reading in MCS. 
Table 3. Regression on ALSPAC Standardised Entry Assessment scores

\begin{tabular}{|c|c|c|}
\hline & $\begin{array}{c}\text { Reading } \\
\beta \\
\text { (SE) }\end{array}$ & $\begin{array}{c}\text { Mathematics } \\
\beta \\
\text { (SE) }\end{array}$ \\
\hline \multicolumn{3}{|l|}{ Number of times workless (S1-S4) } \\
\hline Workless $\times 1$ & $\begin{array}{l}-0.019 \\
(0.058)\end{array}$ & $\begin{array}{l}-0.036^{*} \\
(0.057)\end{array}$ \\
\hline Workless $\times 2$ & $\begin{array}{l}-0.008 \\
(0.079)\end{array}$ & $\begin{array}{l}-0.016 \\
(0.078)\end{array}$ \\
\hline Workless $\times 3+$ & $\begin{array}{l}-0.044^{*} \\
(0.072)\end{array}$ & $\begin{array}{l}-0.033^{*} \\
(0.071)\end{array}$ \\
\hline \multicolumn{3}{|l|}{ Associated Risks } \\
\hline Age of mother at birth (years) (S1) & $\begin{array}{l}0.035^{*} \\
(0.004)\end{array}$ & $\begin{array}{l}0.033^{*} \\
(0.003)\end{array}$ \\
\hline Ethnicity (S1) & -0.001 & -0.003 \\
\hline $0=$ White, $1=$ other & $(0.091)$ & $(0.090)$ \\
\hline Physical health (S1 - S4) & -0.009 & -0.008 \\
\hline $0=$ good, $1=$ poor $\mathrm{S} 1$ or $\mathrm{S} 4$ & $(0.052)$ & $(0.051)$ \\
\hline \multicolumn{3}{|l|}{$\begin{array}{l}\text { (Edinburgh Post-natal depression scale, Cox et al } \\
\text { 1987) }\end{array}$} \\
\hline range: $0-16$ & $(0.005)$ & $(0.005)$ \\
\hline \multicolumn{3}{|l|}{ Housing tenure $(\mathrm{S} 1)$} \\
\hline $0=$ own, $1=$ rent (social) & $\begin{array}{l}-0.047^{* *} \\
(0.054)\end{array}$ & $\begin{array}{l}-0.054^{* *} \\
(0.054)\end{array}$ \\
\hline $0=$ own, $2=$ rent (private) & $\begin{array}{l}-0.040^{* *} \\
(0.076)\end{array}$ & $\begin{array}{l}-0.040^{* *} \\
(0.075)\end{array}$ \\
\hline $0=$ own, $3=$ other & $\begin{array}{l}-0.013 \\
(0.108)\end{array}$ & $\begin{array}{l}-0.021 \\
(0.107)\end{array}$ \\
\hline $\begin{array}{l}\text { Overcrowded home }(\mathrm{S} 4) \\
0=<1,1=1+\text { per room }\end{array}$ & $\begin{array}{l}-0.036^{* *} \\
(0.035)\end{array}$ & $\begin{array}{l}-0.041^{* *} \\
(0.035)\end{array}$ \\
\hline Weekly family income (S3) & $-0.052^{* *}$ & $\begin{array}{l}-0.069^{* * *} \\
(0.015)\end{array}$ \\
\hline \multicolumn{3}{|l|}{ Parent highest qualification (S1) } \\
\hline $0=$ degree, $1=A^{\prime}$ Level & $\begin{array}{c}-0.152^{* * *} \\
(0.041)\end{array}$ & $\begin{array}{c}-0.145^{* * *} \\
(0.040)\end{array}$ \\
\hline $0=$ degree, $2=O^{\prime}$ Level & $\begin{array}{c}-0.161^{* * *} \\
(0.045)\end{array}$ & $\begin{array}{c}-0.152^{* * *} \\
(0.045)\end{array}$ \\
\hline $0=$ degree, $3=$ vocational & $\begin{array}{l}-0.108^{* * *} \\
(0.070)\end{array}$ & $\begin{array}{l}-0.114^{* * *} \\
(0.069)\end{array}$ \\
\hline $0=$ degree, $4=$ cse & $\begin{array}{c}-0.156^{* * *} \\
(0.066)\end{array}$ & $\begin{array}{c}-0.151^{* * *} \\
(0.065)\end{array}$ \\
\hline Mother took exam (S4) & 0.017 & 0.013 \\
\hline & $(0.053)$ & $(0.052)$ \\
\hline \multicolumn{3}{|l|}{ Marital status (S1) } \\
\hline $0=$ married, $1=$ cohabiting & $\begin{array}{l}-0.021 \\
(0.041)\end{array}$ & $\begin{array}{l}-0.008 \\
(0.041)\end{array}$ \\
\hline $0=$ married, $2=$ single parent & $\begin{array}{c}0.026 \\
(0.092)\end{array}$ & $\begin{array}{c}0.032 \\
(0.090)\end{array}$ \\
\hline No of marital transitions (S1-S4) & 0.024 & 0.031 \\
\hline Range: $0=$ none, $1=1+$ & $(0.044)$ & $(0.043)$ \\
\hline
\end{tabular}




\begin{tabular}{lcc} 
Child Characteristics & & \\
Birthweight & 0.028 & $0.038^{* *}$ \\
Range: 200-5640 grms & $(0.000)$ & $(0.000)$ \\
Gender & $0.106^{* * *}$ & $0.084^{* * *}$ \\
0=boy, 1=girl & $(0.028)$ & $(0.028)$ \\
Health in last year (1y 6m-3y 6m) & 0.008 & 0.014 \\
0=never well/sometimes unwell , 1=always well & $(0.051)$ & $(0.050)$ \\
Age of child (at assessment) & $0.261^{* * *}$ & $0.297^{* * *}$ \\
Range: $4.1-5.3$ yrs & $(0.045)$ & $(0.044)$ \\
Child behaviour (Rutter) (3y 6m) & -0.018 & $-0.042^{* *}$ \\
Range: 0-52 & $(0.003)$ & $(0.003)$ \\
Vocabulary score (3y 2m) & $0.185^{* * *}$ & $0.173^{* * *}$ \\
Range: 0-246 & $(0.001)$ & $(0.001)$ \\
Home-Learning Environment & & \\
\hline Reads to child (2y) & $0.068^{* * *}$ & $0.038^{*}$ \\
0=never.....4=everyday & $(0.018)$ & $(0.018)$ \\
Taken to library (3y 6m) & $0.049^{* *}$ & $0.065^{* * *}$ \\
0=never....3=every week & $(0.014)$ & $(0.014)$ \\
Regular bedtime (2y 6m) & 0.024 & $0.034^{*}$ \\
0=9pm+, 1=8pm, 2=7pm & $(0.019)$ & $(0.019)$ \\
Mother teaching score (3y 6m) & $0.047^{* *}$ & $0.063^{* * *}$ \\
Range: 0-3 & $(0.025)$ & $(0.025)$ \\
\hline$R^{2}$ & 0.237 & 0.257 \\
Observations & 3790 & 3790 \\
\hline Notes. Standardized beta coefficients; Standard errors in parentheses. ${ }^{*} p<0.05,{ }^{* *} p<0.01,^{* * *} p<0.001$
\end{tabular}


Table 4. Regression on MCS standardised FSP scores

\begin{tabular}{|c|c|c|}
\hline & $\begin{array}{c}\text { Reading } \\
\beta \\
\text { (SE) }\end{array}$ & $\begin{array}{c}\text { Mathematics } \\
\beta \\
\text { (SE) }\end{array}$ \\
\hline \multicolumn{3}{|l|}{ Number of times workless (S1-S3) } \\
\hline Workless x 1 & $\begin{array}{l}-0.031 \\
(0.060)\end{array}$ & $\begin{array}{l}-0.033^{*} \\
(0.052)\end{array}$ \\
\hline Workless x 2 & $\begin{array}{l}-0.018 \\
(0.066)\end{array}$ & $\begin{array}{l}-0.033^{*} \\
(0.060)\end{array}$ \\
\hline Workless x 3 & $\begin{array}{l}-0.052^{* *} \\
(0.073)\end{array}$ & $\begin{array}{c}-0.076^{* * *} \\
(0.078)\end{array}$ \\
\hline \multicolumn{3}{|l|}{ Associated Risks } \\
\hline 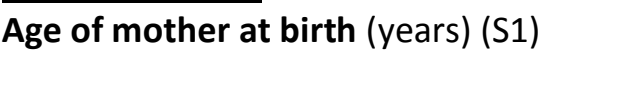 & $\begin{array}{l}0.005 \\
(0.002)\end{array}$ & $\begin{array}{l}-0.006 \\
(0.002)\end{array}$ \\
\hline Ethnicity (S1) & $-0.036^{*}$ & -0.028 \\
\hline $0=$ White, $1=$ other & $(0.048)$ & $(0.047)$ \\
\hline Long-standing illness (S1 - S3) & $-0.029^{*}$ & -0.013 \\
\hline $0=$ none, $1=$ yes [S1 or S3], 2=yes, both & $(0.026)$ & $(0.025)$ \\
\hline Mother depression score (S1) & 0.003 & 0.009 \\
\hline $\begin{array}{l}\text { (Malaise scale, Rutter et al 1970) } \\
\text { (range: 0-9) }\end{array}$ & $(0.008)$ & $(0.008)$ \\
\hline \multicolumn{3}{|l|}{ Housing tenure $(\mathrm{S} 1)$} \\
\hline $0=o w n, 1=$ rent (social) & $\begin{array}{l}-0.059^{* *} \\
(0.049)\end{array}$ & $\begin{array}{l}-0.040 \\
(0.046)\end{array}$ \\
\hline $0=$ own, $2=$ rent (private) & $\begin{array}{l}-0.034^{*} \\
(0.048)\end{array}$ & $\begin{array}{l}-0.016 \\
(0.049)\end{array}$ \\
\hline $0=$ own, $3=$ other & $\begin{array}{l}-0.032^{*} \\
(0.067)\end{array}$ & $\begin{array}{l}-0.018 \\
(0.064)\end{array}$ \\
\hline Overcrowded home (S3) & $-0.033^{*}$ & $-0.054^{* *}$ \\
\hline $0=<1,1=1+$ per room & $(0.056)$ & $(0.064)$ \\
\hline Poverty (OECD median income) (S1) & -0.023 & 0.003 \\
\hline $0=60 \%$ or above, $1=$ below $60 \%$ & $(0.037)$ & $(0.038)$ \\
\hline \multicolumn{3}{|l|}{ Highest qualification ( $h^{\prime}$ hold) (S1) } \\
\hline $0=N \vee Q 4+, 1=N \vee Q 3$ & $\begin{array}{c}-0.075^{* * *} \\
(0.032)\end{array}$ & $\begin{array}{c}-0.057^{* * *} \\
(0.034)\end{array}$ \\
\hline $0=N V Q 4+, 2=N \vee Q 2$ & $\begin{array}{c}-0.086^{* * *} \\
(0.036)\end{array}$ & $\begin{array}{c}-0.079^{* * *} \\
(0.034)\end{array}$ \\
\hline $0=$ NVQ4+, 3=NVQ1/overseas & $\begin{array}{c}-0.060^{* * *} \\
(0.057)\end{array}$ & $\begin{array}{c}-0.066^{* * *} \\
(0.056)\end{array}$ \\
\hline $0=N V Q 4+, 4=$ no qualifications & $\begin{array}{c}-0.058^{* * *} \\
(0.064)\end{array}$ & $\begin{array}{c}-0.062^{* * *} \\
(0.064)\end{array}$ \\
\hline Parent gained higher level qualification & -0.001 & 0.001 \\
\hline & $(0.038)$ & $(0.035)$ \\
\hline \multicolumn{3}{|l|}{ Marital status (S1) } \\
\hline $0=$ married, $1=$ cohabiting & $\begin{array}{l}-0.023 \\
(0.030)\end{array}$ & $\begin{array}{l}-0.016 \\
(0.026)\end{array}$ \\
\hline $0=$ married, $2=$ single parent & $\begin{array}{l}0.017 \\
(0.049)\end{array}$ & $\begin{array}{l}0.024 \\
(0.050)\end{array}$ \\
\hline $\begin{array}{l}\text { No. of marital transitions (S1-S3) } \\
\text { (range: } 0-2 \text { ) }\end{array}$ & $\begin{array}{l}-0.015 \\
(0.021)\end{array}$ & $\begin{array}{l}0.005 \\
(0.021)\end{array}$ \\
\hline IMD deprivation (employment) (S1) & -0.005 & 0.008 \\
\hline
\end{tabular}




\begin{tabular}{|c|c|c|}
\hline & $\begin{array}{c}\text { Reading } \\
\beta \\
(\mathrm{SE}) \\
(0.006)\end{array}$ & $\begin{array}{c}\text { Mathematics } \\
\beta \\
(\mathrm{SE}) \\
(0.006)\end{array}$ \\
\hline \multicolumn{3}{|l|}{ Child Characteristics } \\
\hline Child's birthweight (S1) & $\begin{array}{c}0.022 \\
(0.022)\end{array}$ & $\begin{array}{l}0.032^{*} \\
(0.022)\end{array}$ \\
\hline Child's gender (S1) & $0.069^{* * *}$ & 0.008 \\
\hline $1=$ boy, $2=$ girl & $(0.023)$ & $(0.022)$ \\
\hline Child's age at interview (S3) & $0.190^{* * *}$ & $0.208^{* * *}$ \\
\hline Range: 4.4-6.1 years & $(0.000)$ & $(0.000)$ \\
\hline Child's behaviour (SDQ) (S3) & $-0.121^{* * *}$ & $-0.163^{* * *}$ \\
\hline Range: 0-34 & $(0.003)$ & $(0.003)$ \\
\hline BAS Naming Vocabulary Score (S2) & $0.224^{* * *}$ & $0.229^{* * *}$ \\
\hline Range: 56-149 & $(0.001)$ & $(0.001)$ \\
\hline Child's General Health (S3) & -0.001 & 0.006 \\
\hline 1=very poor..okay, 2=good/excellent & $(0.016)$ & $(0.017)$ \\
\hline Child has LS IIIness (S3) & 0.006 & 0.029 \\
\hline $1=y e s, 2=$ no & $(0.022)$ & $(0.024)$ \\
\hline \multicolumn{3}{|l|}{ Home Learning Environment } \\
\hline$\overline{\text { Read to child (S2) }}$ & $0.066^{* * *}$ & $0.053^{* * *}$ \\
\hline Range: $1=$ not at all....6=every day & $(0.013)$ & $(0.013)$ \\
\hline Take to library (S2) & $0.033^{*}$ & 0.023 \\
\hline Range:1=never...5=weekly & $(0.010)$ & (0.009) \\
\hline Regular term-time bedtime (S3) & $0.045^{* *}$ & $0.030^{*}$ \\
\hline $1=$ never/sometimes, 2 =usually/always & $(0.018)$ & $(0.016)$ \\
\hline Parent teaching score (S2) & $0.041^{* *}$ & $0.048^{* * *}$ \\
\hline \multicolumn{3}{|l|}{ (e.g. alphabet, numbers, songs) } \\
\hline Range: $0-3$ & $(0.025)$ & $(0.023)$ \\
\hline$R^{2}$ & 0.257 & 0.257 \\
\hline Observations & 5656 & 5656 \\
\hline
\end{tabular}

\section{Summary and Conclusion}

Between 18\% (ALSPAC) and 23\% (MCS) of young children in our study had experienced at least one period of parental worklessness and between 6\% (ALSPAC) and 8\% (MCS) had experienced repeated (persistent) parental worklessness during their first five years of life. This finding is important because it suggests that worklessness is higher in these data than in general population level estimates, which highlights the increased exposure to worklessness among families with young children even in economically 'good' times. Parental worklessness, temporary or repeated, was associated with lower levels of parental education, cohabitation or single parenthood, living in rented and/or overcrowded accommodation and low income. Our evidence on this point is informative from a policy perspective, as it shows that the experience of repeated rather than temporary worklessness appeared to be more likely for those families with lower qualifications and poorer health (MCS). Temporary worklessness, by contrast, was more strongly associated with family instability, overcrowded living conditions and low income particularly in MCS. These findings suggest different pathways towards repeated versus temporary worklessness, and potentially the accumulation and persistence of disadvantage among those families experiencing repeated worklessness. Parental worklessness, and especially repeated worklessness, was associated with a range of additional risk factors, that also impact on the academic performance of young children.

We were also able to contribute to the existing literature by estimating the impact of worklessness on specific cognitive outcomes, namely reading and mathematics. In both cohorts, exposure to temporary 
and repeated parental worklessness was associated with lower reading and mathematics attainment scores for children. Although the strongest associations were found for repeated parental worklessness, the experience of worklessness - even only once - was significantly associated with lower attainment scores. The analysis does show the value of capturing differences between repeated and transitory episodes of worklessness and not just seeing it as a static 'state'. It is important to note here, however, that any correlation observed between parental worklessness and child academic performance is not necessarily causal, since worklessness may be related to other unobserved characteristics of families that determine child outcomes. Despite this caveat, given that our analysis uses rich data and controls for many potential confounding factors, we would argue our results are indicative for policy.

The main conclusion from the research is that young children in primary school who grew up in a workless household, had poorer early academic outcomes and made less progress between age three and five than those living in working families. However, much (but not all) of the association between parental worklessness and their children's early academic progress was attributable to other family socio-demographic characteristics, highlighting the multiple challenges faced by workless families and their children. This implies that whilst targeting workless families for policy purposes might be useful, such families face myriad disadvantages which impact on their children's outcomes and hence there are many potential indicators of children at risk of low achievement in addition to family worklessness.

Regarding the role of the early home-learning environment as a potential resource factor that might ameliorate the association between parental worklessness and children's early academic outcomes, we found that although the measures of early homelearning had a significant positive association with child academic progress, they did not significantly reduce the overall association between parental worklessness and outcomes. This is an important result, suggesting that worklessness is associated with negative outcomes independently of what parents do to construct a positive home-learning environment. That said, some of the home-learning measures that had a positive independent association with early school achievement scores (over and above the other variables included in the model), hold particular interest for future policy and intervention strategies. Reading to a child, teaching basic educational building blocks at a young age and keeping to a regular bedtime, were all positively associated with academic performance during the first year at school, highlighting the importance of the early home learning environment (Dearden et al., 2011; Waldvogel \& Washbrook, 2010) and family rules (Kelly et al., 2013). A child's early verbal skills were also positively associated with their school achievement scores, as was a lack of behaviour problems, in MCS. Our findings thus support policies for encouraging parental investment of time in their children at the earliest stages, particularly regarding support for early verbal skills.

In ALSPAC data, children in a repeated workless household had school achievement scores that were between $0.03-0.04$ of a standard deviation lower than those in households that did not experience worklessness. In MCS, the association was somewhat stronger at 0.05-0.08 of a standard deviation in school achievement scores. This finding might suggest increasing social polarization for the later-born MCS cohort, or children growing up outside Southern England. However, this evidence is not sufficient to draw firm conclusions on this point and further work would usefully explore changes in the impact of worklessness over time and by region.

To end, we note that the findings highlight the role of multiple and interlinked influences on human development (Bronfenbrenner, 1986), the importance of formative years and timing of events (Elder \& Caspi, 1988), as well as the plasticity of development (Lerner, 1984; Rutter, 1987, 2006; Sameroff, 2010). That there remained a significant independent association between repeated parental worklessness and reading and mathematics scores for children in both ALSPAC and MCS, even after controlling for associated socioeconomic risks, child characteristics and measures of early home-learning suggests the need to tackle worklessness in conjunction with the wider range of risks these families face.

Future research should examine in more detail the combination and patterns of risks in workless families, and what combination of resource factors can help young children to 'beat the odds'. Of particular interest would be the different experiences facing lone parent families and families with and without access to high quality pre-school provision. 


\section{References}

Belsky, J. (1984). The determinants of parenting: a process model. Child Development, 55, 83-96. http://dx.doi.org/10.2307/1129836

Blanden, J., Gregg, P., \& Macmillan, L. (2007). Accounting for Intergenerational Income Persistence: Noncognitive Skills, Ability and Education. Royal Economic Society 117, C43-C60

Bradley, R. H., Corwyn, R. F., McAdoo, H. P., \& Coll, C. G. (2001). The home environments of children in the United States part I: Variations by age, ethnicity, and poverty status. Child Development, 72, 18441867. http://dx.doi.org/10.1111/1467-8624.t01-1-00382

Brewer, M., Browne, J., \& Joyce, R. (2011). Child and working-age poverty from 2010 to 2020. London: Institute for Fiscal Studies. http://www.ifs.org.uk/comms/comm121.pdf

Bronfenbrenner, U. (1986). Ecology of the family as a context for human development: Research perspectives. Developmental Psychology 22, 723-742 http://dx.doi.org/10.1037/0012-1649.22.6.723

Cherlin, A. J., Kiernan, K. E., \& Chase-Lansdale, P. L. (1995). Parental divorce in childhood and demographic outcomes in young adulthood. Demography, 32, 425-436. http://dx.doi.org/10.2307/2061682

Clarke, A. \& Oswald, A. (1994). Unhappiness and Unemployment. Economic Journal, 104, 648-659. http://dx.doi.org/10.2307/2234639

Clark, A., Georgellis, Y. \& Sanfey, P. (2001). Scarring: The Psychological Impact of Past Unemployment, Economica, London School of Economics and Political Science, 68, 221-41.

De Graaf, P., \& Ultee, W. (2000). United in employment, united in unemployment? Employment and unemployment of couples in the European Union in 1994. In D. Gallie, S. Paugam \& Serge (Eds.), Welfare regimes and the experience of unemployment in Europe (pp. 265-285). Oxford: Oxford University Press.

Dearden, L., Mclntosh, S., Myck, M. \& Vignoles, A. (2002). The Returns to Academic, Vocational and Basic Skills in Britain. Bulletin of Economic Research, 54, 249-274. http://dx.doi.org/10.1111/1467-8586.00152

Dearden, L., Sibieta, L., \& Sylva, K. (2011). The socio-economic gradient in early child outcomes: evidence from the Millennium Cohort Study. Longitudinal and Life Course Studies, 2, 19-40.

Denny, K., Harman, C. \& O'Sullivan, V. (2003) Education, Earnings and Skillls: a multi-country comparison. Institute of Fiscal Studies working paper W04/08. London: Institute of Fiscal Studies.

Doiron, D., \& Mendolia, S. (2011). The impact of job loss on family dissolution. [Article]. Journal of Population Economics, 25, 367-398. doi: 10.1007/s00148-010-0353-5 http://dx.doi.org/10.1007/s00148-010-0353-5

Duncan, G. J., Brooks-Gunn, J., Yeung, J., \& Smith, J. R. (1998). How much does childhood poverty affect the life chances of children? American Sociological Review, 63, 406-423. http://dx.doi.org/10.2307/2657556

Ekhaugen, T. (2009) 'Extracting the causal component from the intergenerational correlation in unemployment' Journal of Population Economics, 22, 97-113. http://dx.doi.org/10.1007/s00148-007-0170-7

Elander, J., \& Rutter, M. (1996). Use and development of the Rutter parents' and teachers' scales. International Journal of Methods in Psychiatric research, 6, 63-78. http://dx.doi.org/10.1002/(SICI)1234-988X(199607)6:2<63::AID-MPR151>3.3.CO;2-M

Elder, G. H., \& Caspi, A. (1988). Economic-Stress in Lives - Developmental Perspectives. Journal of Social Issues, 44, 25-45. http://dx.doi.org/10.1111/i.1540-4560.1988.tb02090.x

Elliot, C. D. $(1983,1996)$. British Ability Scales II: Core Scale 2. Berkshire: The NFER-NELSON Publishing Company Ltd.

Elliot, C. D., Smith, P., \& McCulloch, K. (1996). British Ability Scales II: Administration and Scoring Manual. Berkshire: The NFER-NELSON Publishing Company Ltd.

Elliott, J., \& Shepherd, P. (2006). Cohort Profile: 1970 British Birth Cohort (BCS70). International Journal of Epidemiology, 35, 836-843. http://dx.doi.org/10.1093/ije/dyl174

Ermisch, J., Francesconi, M., \& Pevalin, D. J. (2004). Parental partnership and joblessness in childhood and their influence on young people's outcomes. Journal of the Royal Statistical Society Series a-Statistics in Society, 167, 69-101. doi: 10.1111/j.1467-985X.2004.00292.x

Evans, G. W. (2006). Child development and the physical environment. Annual Review of Psychology, 57, 423-451. doi: 10.1146/annurev.psych.57.102904.190057 http://dx.doi.org/10.1146/annurev.psych.57.102904.190057

Eurostat . (2010). http://ec.europa.eu/eurostat

Feinstein, L. (2003). Inequality in the Early Cognitive Development of British Children in the 1970 Cohort. Economica, 70, 73-98.http://dx.doi.org/10.1111/1468-0335.t01-1-00272

Fenson, L., Dale, P., Reznick, J. S., Thal, D., Bates, E., Hartung, J., Pethick, S. \& Reilly, J. (1993). MacArthur Communicative Inventories: User's Guide and Technical Manual. San Diego: Singular Publishing Group.

Field, F. (2010). The Foundation Years: Preventing Poor Children Becoming Poor Adults. Final report of the 
Independent Review on Poverty and Life Chances, conducted by Frank Field, published on December $3 r d 2010$.

Foundation Stage Profile Handbook (2003). Qualifications and Curriculum Authority. http://www.pgce.soton.ac.uk/ict/NewPGCE/IWB/PNS/content/downloads/publications/foundation/ qca fs profilehbk 031006.pdf

Fraser, A., Macdonald-Wallis, C., Tilling, K., Boyd, A., Golding, J., Davey Smith, G., Henderson, J., Macleod, J., Molloy, L., Ness, A., Ring, S., Nelson, S. \& Lawlor, A. (2012). Cohort Profile: The Avon Longitudinal Study of Parents and Children: ALSPAC mothers cohort. International Journal of Epidemiology, advanced assess published April 2012 doi:10.1093/ije/dys066

Garmezy, N. (1991). Resiliency and Vulnerability to Adverse Developmental Outcomes Associated with Poverty. American Behavioral Scientist, 34, 416-430. http://dx.doi.org/10.1177/0002764291034004003

George, A., Stokes, L., \& Wilkinson, D. (2012). Does early education influence Key Stage 1 attainment? Evidence from England for the Millennium Cohort Study. National Institute Economic Review, 222, 67-80. http://dx.doi.org/10.1177/002795011222200106

Gingerbread (2012) http://www.gingerbread.org.uk/content.aspx?CategorylD=365

Gottschalk, P. (1996). 'Is the correlation in welfare participation across generations spurious?' Journal of Public Economics, 63, 1-25. http://dx.doi.org/10.1016/S0047-2727(96)01585-X

Golding, J., Pembrey, M., Jones, R., \& the ALSPAC study team. (2001). ALSPAC: the Avon Longitudinal Study of Parents and Children. I. Study methodology. Paediatric and Perinatal Epidemiology, 15, 74-87. http://dx.doi.org/10.1046/i.1365-3016.2001.00325.x

Goodman, R. (1997). The Strengths and Difficulties Questionnaire: A Research Note. Journal of Child Psychology and Psychiatry, 38, 581-586. http://dx.doi.org/10.1111/j.1469-7610.1997.tb01545.x Gregg, P., Harkness, S., \& Machin, S. (1999). Poor Kids: Trends in Child Poverty in Britain, 1968-96, Fiscal Studies, 20, 163-187. http://dx.doi.org/10.1111/i.1475-5890.1999.tb00009.x

Gregg, P., \& Macmillan, L. (2009). Family Income and Education in the Next Generation: Exploring income gradients in education for current cohorts of youth. The Centre for Market and Public Organisation 09/223, Department of Economics, University of Bristol, UK.

Gregg, P., \& Wadsworth, J. (2001). Everything you ever wanted to know about measuring worklessness and polarization at the household level but were afraid to ask. Oxford Bulletin of Economics and Statistics, 63, 777-806. http://dx.doi.org/10.1111/1468-0084.63.spe1.9

Grinyer, J. (2006). Literacy, numeracy and the labour market: further analysis of the Skills for Life survey. Nottingham: Department for Education and Skills.

Groot, W., \& Massed van der Brink, H. (2006). Dormant Capital: a Research into the Social Expenses of Low Literacy. Amsterdam: University of Amsterdam.

Hansen, K. (with contributions from Johnson, J., Joshi, H., Calderwood, L., Jones, E., Mcdonald, J., Shepherd, P., Smith, K. and the Millennium Cohort Team). (2010). Millennium Cohort Study first, second, third and fourth surveys: A guide to the datasets (5th edition). London: Centre for Longitudinal Studies, Institute of Education.

Haveman, R. H., \& Wolfe, B. (1994). Succeeding generations: on the effects of investments in children. New York: Russell Sage Foundation.

Heckman, J. J. (2006). Skill formation and the economics of investing in disadvantaged children. Science, 312, 1900-1912. http://dx.doi.org/10.1126/science.1128898

Heckman, J. J. \& Masterov, D.V. (2007). The Productivity Argument for Investing in Young Children. Review of Agricultural Economics 29, 446-493. http://dx.doi.org/10.1111/i.1467-9353.2007.00359.x

Hertzman, C., Siddiqi, A., Hertzman, E., Irwin, L. G., Vaghri, Z., Houweling, T. A. J., Bell, R., Tinajero, A. \& Marmot, M. (2010). Bucking the inequality gradient through early child development. British Medical Journal, 340, 346-348. http://dx.doi.org/10.1136/bmj.c468

Jerrim, J. \& Vignoles, A. (in press). Social mobility, regression to the mean and the cognitive development of high ability children from disadvantaged homes. Journal of the Royal Statistical Society (series A).

Kelly, Y., Kelly, J., \& Sacker, A. (2013). Time for bed: associations with cognitive performance in 7-year-old children: a longitudinal population-based study. Journal of Epidemiology and Community Health, Online First, July 2013. doi: 10.1136/jech-2012-202024

Kiernan, K. (1997). Becoming a young parent: a longitudinal study of associated factors. British Journal of Sociology, 48, 406-428. http://dx.doi.org/10.2307/591138

Lerner, R. M. (1984). On the nature of human plasticity. New York: Cambridge University Press. http://dx.doi.org/10.1017/CBO9780511666988

Lerner, R. M., \& Benson, P. (2003). Developmental assets and asset-building communities. New York: Kluwer Academic. http://dx.doi.org/10.1007/978-1-4615-0091-9

Machin, S., McIntosh, S., Vignoles, A. \& Viitanen, T. (2001). Basic skills, soft skills and Labour Market Outcomes: secondary analysis of the National Child Development Study. DfEE research report No. 250. London: Department for Education and Employment. 
Macmillan, L. (2010). The intergenerational transmission of worklessness in the UK. Bristol: The Centre for Market and Public Organisation (CMPU).

Macmillan, L. (2011). Measuring the intergenerational correlation of worklessness. Working Paper No. 11/278 Centre for Market and Public Organisation, Bristol Institute of Public Affairs, University of Bristol.

Maplethorpe, N., Chanfreau, J., Philo, D., \& Tait, C. (2010). Families with children in Britain: Findings from the 2008 Families and Children Study (FACS). Department for Work and Pensions, Research Report No 656 https://www.gov.uk/government/uploads/system/uploads/attachment data/file/214426/rrep656. pdf

Marmot, M. (2010). Fair Society Healthy Lives. The Marmot Review: Strategic Review of Health Inequalities in England post 2010. http://www.ucl.ac.uk/gheg/marmotreview/FairSocietyHealthyLives

Masten, A. S. (2007). Resilience in developing systems: Progress and promise as the fourth wave rises. Development and Psychopathology, 19, 921-930. http://dx.doi.org/10.1017/S0954579407000442

Masten, A. S. (2009). Ordinary Magic: Lessons from research on resilience in human development. . Education Canada, 49, 28-32.

Melhuish, E. C., Sylva, K., Sammons, P., Siraj-Blatchford, I., Taggart, B., \& Phan, M. (2008). Effects of the Home Learning Environment and preschool center experience upon literacy and numeracy development in early primary school. Journal of Social Issues, 64, 95-114. http://dx.doi.org/10.1111/j.1540-4560.2008.00550.x

McIntosh, S., \& Vignoles, A. (2001). Measuring and assessing the impact of basic skills on labour market outcomes. Oxford Economic Papers, 53, 453-481. http://dx.doi.org/10.1093/oep/53.3.453

McKee-Ryan, F. M., Song, Z. L., Wanberg, C. R., \& Kinicki, A. J. (2005). Psychological and physical well-being during unemployment: A meta-analytic study. Journal of Applied Psychology, 90, 53-76. http://dx.doi.org/10.1037/0021-9010.90.1.53

McLanahan, S., \& Sandefur, G. (1994). Growing up with a single parent: What hurts, what helps? Cambridge, MA: Harvard University Press.

O'Neill, D., \& Sweetman, O. (1998). Intergenerational Mobility in Britain: Evidence from Unemployment Patterns. Oxford Bulletin of Economics and Statistics, 60, 431-449. http://dx.doi.org/10.1111/1468-0084.00108

ONS. (2011). Working and Workless Households, 2011 - Statistical Bulletin, http://www.ons.gov.uk/ons/dcp171778 229480.pdf

Page, M. (2004). New Evidence on Intergenerational Correlations in Welfare Participation, in M. Corak (Ed.) Generational Income Mobility in North America and Europe, (pp. 226-243). Cambridge: Cambridge University Press. http://dx.doi.org/10.1017/CBO9780511492549.011

Plewis, I. (2007). Non-Response in a Birth Cohort Study: The Case of the Millennium Cohort Study. International Journal of Social Research Methodology, 10, 325-334. http://dx.doi.org/10.1080/13645570701676955

Rutter, M., Tizard, J., \& Whitmore, K. (1970). Education, health and behaviour. London: Longmans.

Rutter, M. (1981). Stress, Coping and Development - Some Issues and Some Questions. Journal of Child Psychology and Psychiatry and Allied Disciplines, 22, 323-356. http://dx.doi.org/10.1111/j.1469-7610.1981.tb00560.x

Rutter, M. (1987). Psychosocial Resilience and Protective Mechanisms. American Journal of Orthopsychiatry, 57, 316-331. http://dx.doi.org/10.1111/j.1939-0025.1987.tb03541.x

Rutter, M. (2006). Implications of Resilience Concepts for Scientific Understanding. Annals of the New York Academy of Science, 1094, 1-12. doi: 10.1196/annals.1376.002 http://dx.doi.org/10.1196/annals.1376.002

Rutter, M. (2009). Understanding and testing risk mechanisms for mental disorders. [Article]. Journal of Child Psychology and Psychiatry, 50, 44-52. doi: 10.1111/j.1469-7610.2008.01976.x http://dx.doi.org/10.1111/j.1469-7610.2008.01976.x

Sameroff, A. J. (2010). A Unified Theory of Development: A Dialectic Integration of Nature and Nurture. Child Development, 81, 6-22. http://dx.doi.org/10.1111/j.1467-8624.2009.01378.x

Schoon, I. (2006). Risk and Resilience: Adaptations to changing times. Cambridge: Cambridge University Press http://dx.doi.org/10.1017/CBO9780511490132

Schoon, I., Barnes, M., Parsons, S., Brown, V., Ross, A., \& Vignoles, A. (2012). Intergenerational transmission of worklessness: Evidence from the Millennium Cohort and the Longitudinal Study of Young People in England: Department for Education. DFE-RR-234. https://www.education.gov.uk/publications/eOrderingDownload/DFE-RR234.pdf

Schoon, I., Bynner, J., Joshi, H., Parsons, S., Wiggins, R. D., \& Sacker, A. (2002). The influence of context, timing, and duration of risk experiences for the passage from childhood to midadulthood. Child Development, 73, 1486-1504. http://dx.doi.org/10.1111/1467-8624.00485

Schoon, I., Hope, S., Ross, A., \& Duckworth, K. (2010). Family hardship and children's development: the early years. Longitudinal and Life Course Studies, 1, 209-222. 
Social Exclusion Unit Report (2004). Mental health and social exclusion. The Office of the Deputy Prime Minister. http://www.socialfirmsuk.co.uk/resources/library/mental-health-and-social-exclusionsocial-exclusion-unit-report

South Gloucestershire Professional and Curriculum Support Service. (1996). Entry Assessment in South Gloucestershire. Weston-super-mare: Woodspring Educational Resource Centre.

Such, E,. \& Walker, R. (2002). Falling behind? Research on transmitted deprivation. Benefits, 35, 10, issue 3 , 185-92

Sylva, K., Melhuish, E., Sammons, P., Siraj-Blatchford, \& I. Taggart, B. (Eds.). (2010). Early Childhood Matters: Evidence from the Effective Pre-school and Primary Education Project. London: Routledge.

Vignoles, A., de Coulon, A., \& Marcenaro-Gutierrez, O. (2011). The value of basic skills in the British labour market. Oxford Economic Papers, 63, 27-48. http://dx.doi.org/10.1093/oep/gpq012

Waldfogel, J., \& Washbrook, E. (2010). Low income and early cognitive development in the UK: Sutton Trust. http://www.suttontrust.com/our-work/research/item/low-income-and-early-cognitivedevelopment-in-the-uk

Washbrook, E. (2010). Early Environments and Child Outcomes:An Analysis Commission for the Independent Review on Poverty and Life Chances. Bristol: Centre for Market and Public Organization, University of Bristol. http://www.bristol.ac.uk/ifssoca/outputs/eeco.pdf

\section{Appendix}

Table A1. Relationship between parental worklessness and potential protective factors (ALSPAC)

\begin{tabular}{|c|c|c|c|c|c|c|}
\hline & $\begin{array}{c}0 \\
\text { Workless } \\
\%\end{array}$ & $\begin{array}{c}1 \\
\text { Workless } \\
\%\end{array}$ & $\begin{array}{c}2 \\
\text { Workless } \\
\%\end{array}$ & $\begin{array}{c}3+ \\
\text { Workless } \\
\%\end{array}$ & $\begin{array}{l}\text { All } \\
\%\end{array}$ & $N$ (all) \\
\hline \multicolumn{7}{|l|}{ Child Characteristics } \\
\hline Mean birthweight (kg) & 3.5 & 3.4 & 3.4 & 3.3 & 3.4 & 6871 \\
\hline Gender ( $\%$ female) & 48.6 & 49.1 & 47.7 & 49.1 & 48.6 & 6942 \\
\hline $\begin{array}{l}\text { Good health in last year } \\
\text { (1y } 6 m-3 y 6 m)\end{array}$ & 91.9 & 89.6 & 87.9 & 86.0 & 91.2 & 6939 \\
\hline $\begin{array}{l}\text { Mean age of child (at Entry } \\
\text { Assessments) }\end{array}$ & 4.6 & 4.5 & 4.5 & 4.6 & 4.6 & 5041 \\
\hline $\begin{array}{l}\text { Mean behaviour score } \\
\text { (SDQ) }(3 y \mathrm{y})\end{array}$ & 12.3 & 12.8 & 13.6 & 13.6 & 12.5 & 6742 \\
\hline $\begin{array}{l}\text { Mean Vocabulary score } \\
\text { (3y } 2 \mathrm{~m}) \\
\text { Child school experiences } \\
\end{array}$ & 230.0 & 228.1 & 225.5 & 223.3 & 229.3 & 6767 \\
\hline $\begin{array}{l}\text { Always enjoys school }(4 \mathrm{y} \\
6 \mathrm{~m}) \\
\text { Home Learning Environment } \\
\end{array}$ & 68.8 & 67.1 & 68.4 & 74.6 & 69.0 & 6294 \\
\hline $\begin{array}{l}\text { Reads to child everyday } \\
(2 y)\end{array}$ & 63.9 & 52.8 & 49.2 & 41.9 & 61.1 & 6745 \\
\hline $\begin{array}{l}\text { Regular bedtime before } \\
9 \mathrm{pm}(2 \mathrm{y} 6 \mathrm{~m})\end{array}$ & 86.3 & 79.6 & 81.4 & 78.3 & 85.1 & 6654 \\
\hline $\begin{array}{l}\text { Mean teaching score }(3 y \\
6 m)\end{array}$ & 2.6 & 2.7 & 2.6 & 2.6 & 2.6 & 6718 \\
\hline Taken to library (3y 6m) & 69.3 & 64.2 & 62.4 & 57.4 & 67.9 & 6733 \\
\hline n(low-high) & $4109-5703$ & $383-509$ & $224-308$ & $325-422$ & & \\
\hline
\end{tabular}


Table A2. Relationship between parental worklessness and potential protective factors (MCS)

\begin{tabular}{|c|c|c|c|c|c|c|}
\hline & $\begin{array}{c}0 \\
\text { Workless } \\
\%\end{array}$ & $\begin{array}{c}1 \\
\text { Workless } \\
\%\end{array}$ & $\begin{array}{c}2 \\
\text { Workless } \\
\%\end{array}$ & $\begin{array}{c}3 \\
\text { Workless } \\
\%\end{array}$ & $\begin{array}{l}\text { All } \\
\%\end{array}$ & $N(a l l)$ \\
\hline \multicolumn{7}{|l|}{ Child Characteristics } \\
\hline Mean birthweight (kg) & 3.4 & 3.3 & 3.3 & 3.3 & 3.4 & 8232 \\
\hline Gender (\% female) & 49.0 & 50.3 & 49.1 & 51.4 & 49.3 & 8252 \\
\hline $\begin{array}{l}\text { Excellent health in last } \\
\text { year (S3) }\end{array}$ & 54.5 & 41.9 & 41.7 & 41.1 & 51.5 & 8216 \\
\hline $\begin{array}{l}\text { No longstanding illness } \\
\text { (S3) }\end{array}$ & 82.2 & 79.1 & 75.1 & 75.1 & 80.9 & 8207 \\
\hline $\begin{array}{l}\text { Mean age of child (at } \\
\text { interview S3) }\end{array}$ & 5.2 & 5.2 & 5.2 & 5.2 & 5.2 & 8252 \\
\hline $\begin{array}{l}\text { Mean behaviour score } \\
\text { (SDQ) S3 }\end{array}$ & 6.5 & 8.4 & 9.3 & 10.9 & 7.1 & 7020 \\
\hline $\begin{array}{l}\text { Mean BAS Naming } \\
\text { Vocabulary score (S2) }\end{array}$ & 76.0 & 68.9 & 67.4 & 63.6 & 73.9 & 7710 \\
\hline \multicolumn{7}{|l|}{ Home Learning Environment } \\
\hline $\begin{array}{l}\text { Reads to child everyday } \\
\text { (S2) }\end{array}$ & 65.0 & 49.1 & 43.0 & 39.8 & 60.2 & 8252 \\
\hline Regular bedtime (S3) & 65.0 & 62.6 & 61.3 & 58.2 & 64.0 & 8218 \\
\hline Mean teaching score $(\mathrm{S} 2)$ & 2.8 & 2.7 & 2.7 & 2.6 & 2.7 & 8251 \\
\hline Taken to library (S2) & 45.9 & 32.9 & 30.5 & 25.5 & 42.0 & 7730 \\
\hline n(low-high) & $5275-6183$ & $554-748$ & $378-573$ & $450-748$ & & \\
\hline
\end{tabular}

Table A3. Response bias in longitudinal sample of families compared to all families in first wave of data collection in ALSPAC (8 months) and MCS (9 months)

\begin{tabular}{lcr|cr|cr|rr} 
& \multicolumn{4}{c|}{ ALSPAC } & \multicolumn{4}{c}{ MCS } \\
& \multicolumn{2}{c}{ Long sample } & \multicolumn{2}{c|}{ All families } & \multicolumn{2}{c}{ Long sample } & \multicolumn{2}{c}{ All families } \\
& \% & $n$ & \% & $n$ & $\%$ & $n$ & $\%$ & $n$ \\
\hline \% white & $96.9^{*}$ & 6,810 & 95.1 & 12,392 & 85.7 & 8,233 & 84.7 & 9,124 \\
\% home owner & $82.3^{*}$ & 6,904 & 77.1 & 11,239 & 64.4 & 8,236 & 62.0 & 9,124 \\
\% rented (social) & $11.0^{*}$ & 6,904 & 15.0 & 11,239 & 22.3 & 8,236 & 23.7 & 9,124 \\
\% overcrowded home & $22.6^{*}$ & 6,671 & 25.0 & 9,922 & 8.6 & 8,211 & 9.1 & 9,086 \\
(1+ per room) & & & & & & & & \\
\% degree (or equiv)+ & $23.6^{*}$ & 6,827 & 21.3 & 12,511 & 44.8 & 8,241 & 43.3 & 9,129 \\
\% no quals & $8.7^{*}$ & 6,827 & 13.7 & 12,511 & 7.6 & 8,241 & 8.4 & 9,129 \\
\% married & $79.1^{*}$ & 6,942 & 75.2 & 11,246 & 62.3 & 8,252 & 60.8 & 9,146 \\
\% single parent & 3.6 & 6,942 & 4.4 & 11,246 & 12.7 & 8,252 & 13.8 & 9,146 \\
\hline
\end{tabular}

*In both studies t-tests were used to assess if the mean scores for the longitudinal samples differed significantly from the mean score for all participating families. An * indicates differences in the mean scores were significant at the $p<0.05$ level. In both studies the more affluent and privileged were more likely to be part of the longitudinal sample and the more disadvantaged to have dropped out. For example, fewer single parents and more married couples are part of the longitudinal samples as are fewer families living in social rented housing and more home owners. However, whereas these differences were not significant in MCS, all bar one measure showed a significant response bias in the ALSPAC longitudinal sample. The one exception to this was single parents. 


\section{Endnotes}

'Workless working-age households by type of household, 2010 Release http://www.ons.gov.uk/ons/publications/re-reference-tables.html?edition=tcm\%3A77-200008.

ii Fraser et al (2012), suggests that $\sim 80 \%$ of the enrolled pregnancy cohort from ALSPAC completed the questionnaire when the child was 8 months old (see table 1 ).

iii Assessment score from later ages, e.g. Key Stage 1, were available for both cohorts but in this paper we have concentrated on the school assessments of children in their first full year of primary school.

iv Note that since we control for prior cognitive ability of the child the model is akin to a "value added" model.

$\checkmark$ The dependent variable is categorical. For robustness, we estimated an ordered logit regression model and the same set of risk factors were significantly associated with parental worklessness. We present the OLS results for ease of interpretation. 